\title{
MONITORING OF SOME LEPIDOPTERA SP. FROM APPLE ORCHARDS WITH THE HELP OF PHEROMONE TRAPS, IN CONDITIONS OF 2019 IN THE NORTH EAST AREA OF ROMANIA
}

\author{
Agurița Aftudor-Manolache ${ }^{1}$, Cristina Ionela Turcu ${ }^{1 *}$, Margareta Corneanu ${ }^{1}$, Ionel Perju ${ }^{1}$ \\ ${ }^{1}$ Research Station for Fruit Growing, Iaşi România
}

Current Trends in

Natural Sciences

\begin{abstract}
The experience was organized within the Research Station for Fruit Growing Iasi, at Fălticeni Development Center, into intensive apple plantation. As varieties were taken in account Jonathan, Golden delicious and Starkrimson grafted on MM106, planted at distances of $4 \times 2.5$ meters, as a form of crown shape palmette type. For the monitoring of the pests, traps with synthetic sex pheromones such as atraPOM, atraRET, atraBLANC were used for three Lepidoptera sp. from the apple plantation, namely: Cydia pomonella L., Phylonorichter blancardella F., Adoxophyes reticulana Hb. The first two monitored species showed large peaks of flight curves between May and August. The first hibernating larvae of Adoxophyes reticulana $\mathrm{Hb}$ were observed in the crown of trees of Golden and Starkrimson varieties, at April 14, during the leafing period. The first flight of the species Cydia pomonella L. was registered on May 9 and the flight of Phylonorichter blancardella F., butterflies was registered in mid-June. Insecticides were very effective in controlling these pests: Mospilan-0.03\% (0.45kg / ha) for the pink bud phenophase (BBCH 57) and Reldan 22EC -0.15\% (2.2l/ ha) for fruit with a diameter $1 \mathrm{~cm}(\mathrm{BBCH} 71)$ for the biological reserve of Adoxophyes reticulana $\mathrm{Hb}$., larvae; Calypso $0.02 \%(0.3 \mathrm{l} / \mathrm{ha})$ and Coragen $0.15 \mathrm{l} / \mathrm{ha}$ for the second generation of Cydia pomonella $\mathrm{L}$.
\end{abstract}

Keywords: Adoxophyes reticulana Hb., Apple, Cydia pomonella L., Phylonorichter blancardella F.

\section{INTRODUCTION}

Being one of the most important species of fruit trees, an extremely large number of pests and pathogens have been found, with almost 80 diseases caused only by viruses, mycoplasmas, bacteria, fungi and other physiological imbalances. Added to these diseases, there are 64 species of insects and mites, along with 8 species of nematodes and at least 2 species of rodents (Filipescu et al., 2001). Cydia pomonella L., Phylonorichter blancardella F. and Adoxophyes reticulana Hb. they are the most important Lepidopters spp. that attack apple plantations around the world, that's why they have been very studied in recent years.

\section{MATERIALS AND METHODS}

The experience was organized within the Research Station for Fruit Growing Iasi, at Fălticeni Development Center, into intensive apple plantation. As varieties were taken in account Jonathan, Golden delicious and Starkrimson grafted on MM106, planted at distances of $4 \times 2.5$ meters, as a form of crown shape palmette type. For the monitoring of the pests, traps with synthetic sex pheromones such as atraPOM, atraRET, atraBLANC is presented in the figure 1, were used for 


\section{Current Trends in Natural Sciences \\ Vol. 9, Issue 17, pp. 346-351, 2020 \\ https://doi.org/10.47068/ctns.2020.v9i17.044}

Current Trends in Natural Sciences (on-line)

ISSN: 2284-953X

ISSN-L: 2284-9521
Current Trends in Natural Sciences (CD-Rom) ISSN: 2284-9521 ISSN-L: 2284-9521

three Lepidoptera sp. from the apple plantation, namely: Cydia pomonella L., Phylonorichter blancardella F., Adoxophyes reticulana Hb..

The traps were installed on May 5, the distance between the traps being 20 meters, they are located at a height of 1.5 meters in the tree. Pheromones being changed monthly, and supports as many times as needed (even once a week, when a large number of catches were recorded).

The dynamics of catching butterflies with the help of traps with synthetic sex pheromones, in the conditions of 2019, is presented in the figure 2 .

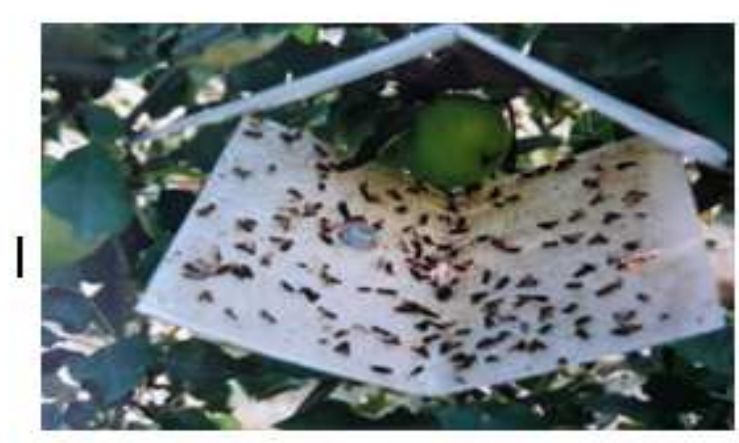

atraPOM traps

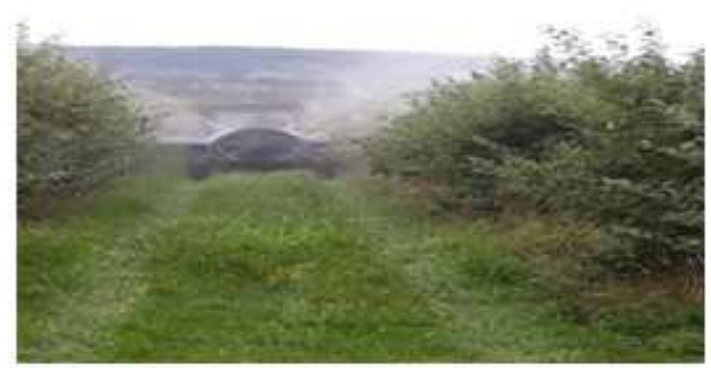

Application of phytosanitary treatments

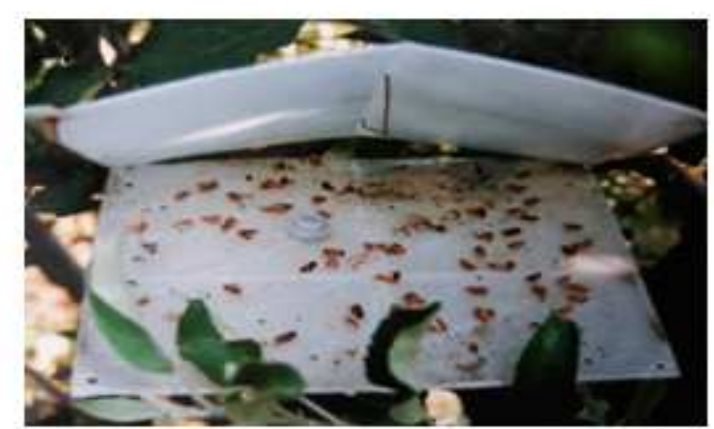

atraRET traps

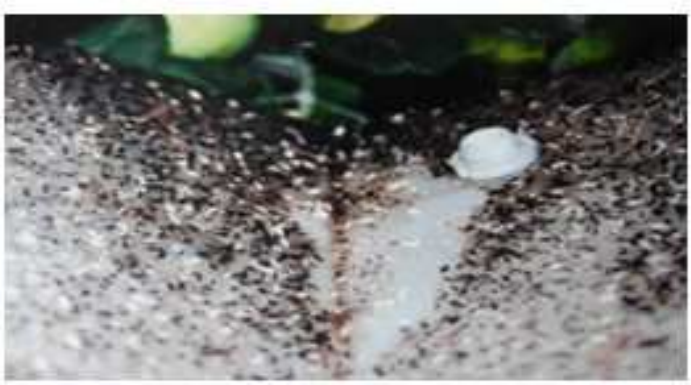

atraBLANC traps

Figure 2. Pheromone traps and application of phytosanitary treatments

\section{RESULTS AND DISCUSSIONS}

The conditions of 2019 were favorable for the development of pests in apple plantations (table 1): Cydia pomonella L., Phylonorichter blancardella F. and Adoxophyes reticulana $\mathrm{Hb}$. The first two monitored species showed large peaks of flight curves between May and August.

The first hibernating larvae of Adoxophyes reticulana $\mathrm{Hb}$. were observed in the crown of trees of Golden and Starkrimson varieties, at April 14, during the leafing period.

The study period was characterized by low precipitation (deviation from the multiannual average being - $66.61 / \mathrm{mm}$ ) distributed unevenly, with hail droughts with prolonged drought periods in March $(-64.0 \mathrm{~mm})$, April $(-7.8 \mathrm{~mm})$, June $(-29.7 \mathrm{~mm})$ and July $(-49.7 \mathrm{~mm})$, being considered 


\section{Current Trends in Natural Sciences}

Vol. 9, Issue 17, pp. 346-351, 2020

https://doi.org/10.47068/ctns.2020.v9i17.044

Current Trends in Natural Sciences (on-line)

ISSN: 2284-953X

Current Trends in Natural Sciences (CD-Rom)

ISSN: 2284-9521

ISSN-L: 2284-9521

ISSN-L: 2284-9521

deficient months from this point of view, and in January, May, August, September and October there was a excess of precipitation, the values of deviation from the multiannual averages being between $+5.8 \mathrm{~mm}$ and $+28.9 \mathrm{~mm}$ (table 1). It should be noted that although June registered a deficit in terms of rainfall compared to the multiannual average, they were unevenly distributed.

Table 1. The evolution of the climatic conditions of the studied period (temperatures, precipitations, humidity)

\begin{tabular}{|c|c|c|c|c|c|}
\hline \multirow{2}{*}{ Month } & \multirow{2}{*}{$\begin{array}{c}\text { Multiannual average } \\
\text { temperature } 2005- \\
2015\left({ }^{\circ} \mathrm{C}\right)\end{array}$} & \multicolumn{3}{|c|}{ Temperature $2019\left({ }^{\circ} \mathrm{C}\right)$} & \multirow{2}{*}{$\begin{array}{l}\text { The deviation from } \\
\text { the multiannual } \\
\text { average }\left({ }^{\circ} \mathrm{C}\right)\end{array}$} \\
\hline & & mean & high & low & \\
\hline I & -1.9 & -3.0 & 10.1 & -14.8 & -4.9 \\
\hline II & -1.2 & 1.9 & 17.6 & -8.5 & 0.7 \\
\hline III & 4.7 & 7.4 & 23.2 & -6.2 & -2.7 \\
\hline IV & 11.4 & 10.5 & 26.3 & -0.3 & 0.9 \\
\hline $\mathbf{V}$ & $\mathbf{1 7 . 0}$ & 15.8 & 28.5 & 2.7 & 1.2 \\
\hline VI & 20.5 & 21.6 & 34.4 & 9.7 & -1.1 \\
\hline VII & 22.4 & 20.9 & 35.4 & 9.1 & 1.5 \\
\hline VIII & 21.9 & 21.8 & 35.0 & 9.3 & 0.1 \\
\hline IX & 16.8 & 16.9 & 34.6 & 1.6 & -0.1 \\
\hline $\mathbf{X}$ & 10.3 & 11.5 & 26.3 & 1.0 & -1.2 \\
\hline XI & 5.4 & 8.29 & 24.4 & -4.4 & +2.9 \\
\hline XII & 0.1 & 2.71 & 16.8 & -6.4 & +2.6 \\
\hline Mean & 10.2 & 11.3 & 35.4 & -14.8 & +1.2 \\
\hline Month & $\begin{array}{c}\text { Multiannual average } \\
\text { precipitation 2005- } \\
2015(\mathrm{~mm})\end{array}$ & $\begin{array}{c}\text { Rainfall } \\
2019 \\
(\mathbf{m m})\end{array}$ & Deviation & $\begin{array}{l}\text { Number days } \\
\text { with rainfall }\end{array}$ & $\begin{array}{c}\text { Humidity } \\
2019 \\
(\%) \\
\end{array}$ \\
\hline I & 35.5 & 47.6 & +12.1 & 13 & 87 \\
\hline II & 32.1 & 28.2 & -3.9 & 8 & 79 \\
\hline III & 71.2 & 7.2 & -64.0 & 6 & 55 \\
\hline IV & 51.4 & 43.6 & -7.8 & 12 & 60 \\
\hline $\mathbf{V}$ & 71.1 & 86.6 & +15.5 & 13 & 75 \\
\hline VI & 82.9 & 53.2 & -29.7 & 13 & 77 \\
\hline VII & 64.7 & 15.0 & -49.7 & 7 & 67 \\
\hline VIII & 50.8 & 56.6 & +5.8 & 8 & 22 \\
\hline IX & 36.5 & 65.4 & +28.9 & 10 & 63 \\
\hline $\mathbf{X}$ & 2.4 & 28.6 & +26.2 & 10 & 82 \\
\hline XI & 33.4 & 6.8 & -26.6 & 7 & 80 \\
\hline XII & 30.6 & 12.2 & -18.4 & 9 & 85 \\
\hline Amount & 562.6 & 451 & -111.6 & 116 & 66.7 \\
\hline
\end{tabular}

The average temperature recorded during the period studied (January-December) ranged from $-3.0^{\circ}$ $\mathrm{C}$ (in January) to $21.8^{\circ} \mathrm{C}$ (in August) (Table 1). The lowest value was recorded on January 8, 2019 $\left(-14.8^{\circ} \mathrm{C}\right)$, and the highest value was $35.4^{\circ} \mathrm{C}$ recorded on July 2.

The first flight of the species Cydia pomonella L. was registered on May 9 and the flight of Phylonorichter blancardella $\mathrm{F}$. butterflies was registered in mid-June.

Cydia pomonella L. recorded for the first generation two flight maxima, respectively of 43 and 57 butterflies on a trap at a reading in May and June. And for the second generation, there were two flight highs, respectively 45 per trap in July and 24 butterflies per trap in August. 


\section{Current Trends in Natural Sciences \\ Vol. 9, Issue 17, pp. 346-351, 2020 \\ https://doi.org/10.47068/ctns.2020.v9i17.044}

Current Trends in Natural Sciences (on-line)

ISSN: 2284-953X

Current Trends in Natural Sciences (CD-Rom)

ISSN: 2284-9521

ISSN-L: 2284-9521

ISSN-L: 2284-9521

Insecticides were very effective in controlling these pests: Mospilan- $0.03 \%(0.45 \mathrm{~kg} / \mathrm{ha})$ for the pink bud phenophase (BBCH 57) and Reldan 22EC $-0.15 \%$ (2.21/ ha) for fruit with a diameter $1 \mathrm{~cm}$ $(\mathrm{BBCH} 71)$ for the biological reserve of Adoxophyes reticulana $\mathrm{Hb}$. larvae; Calypso -0.02\% (0.31 / ha) and Coragen $0.151 /$ ha for the second generation of Cydia pomonella L..

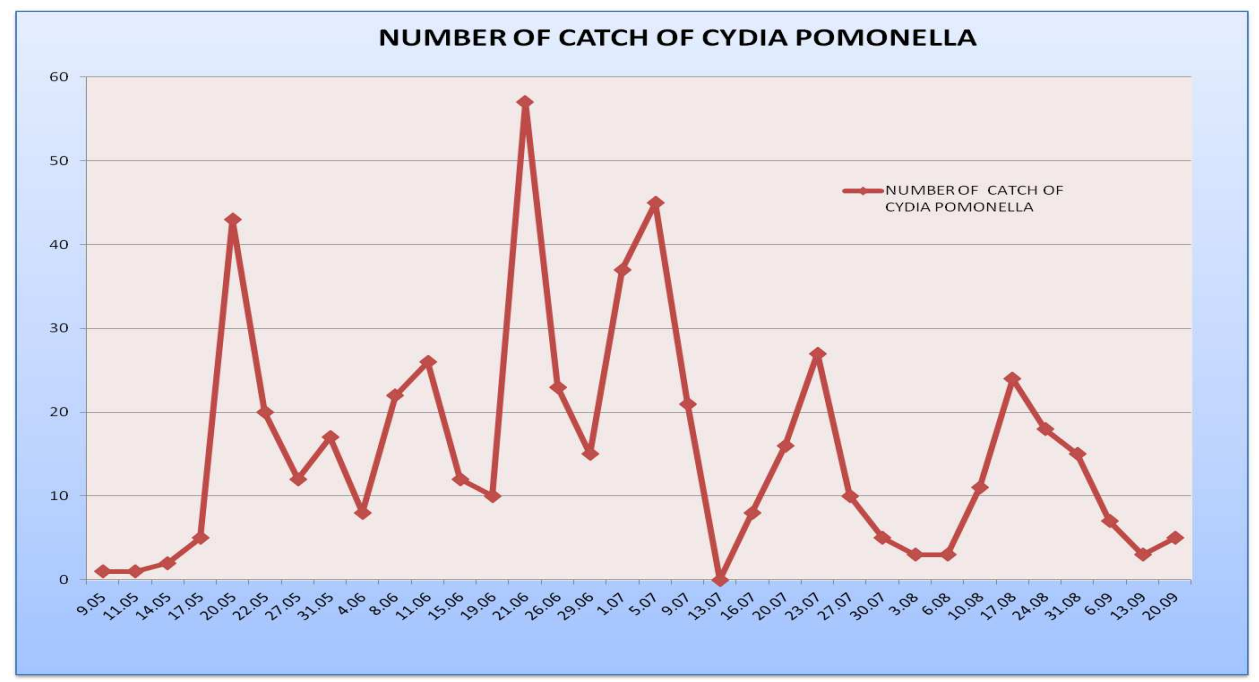

Figure 2. Analysis of flight curves of Cydia pomonella $\mathrm{L}$

Butterflies of the first generation of Adoxophyes reticulana recorded a short flight, lasting about two weeks, at the end of May, with 2-7 butterflies on a trap at one reading, which is a low density compared to the large reserve of hibernating larvae.

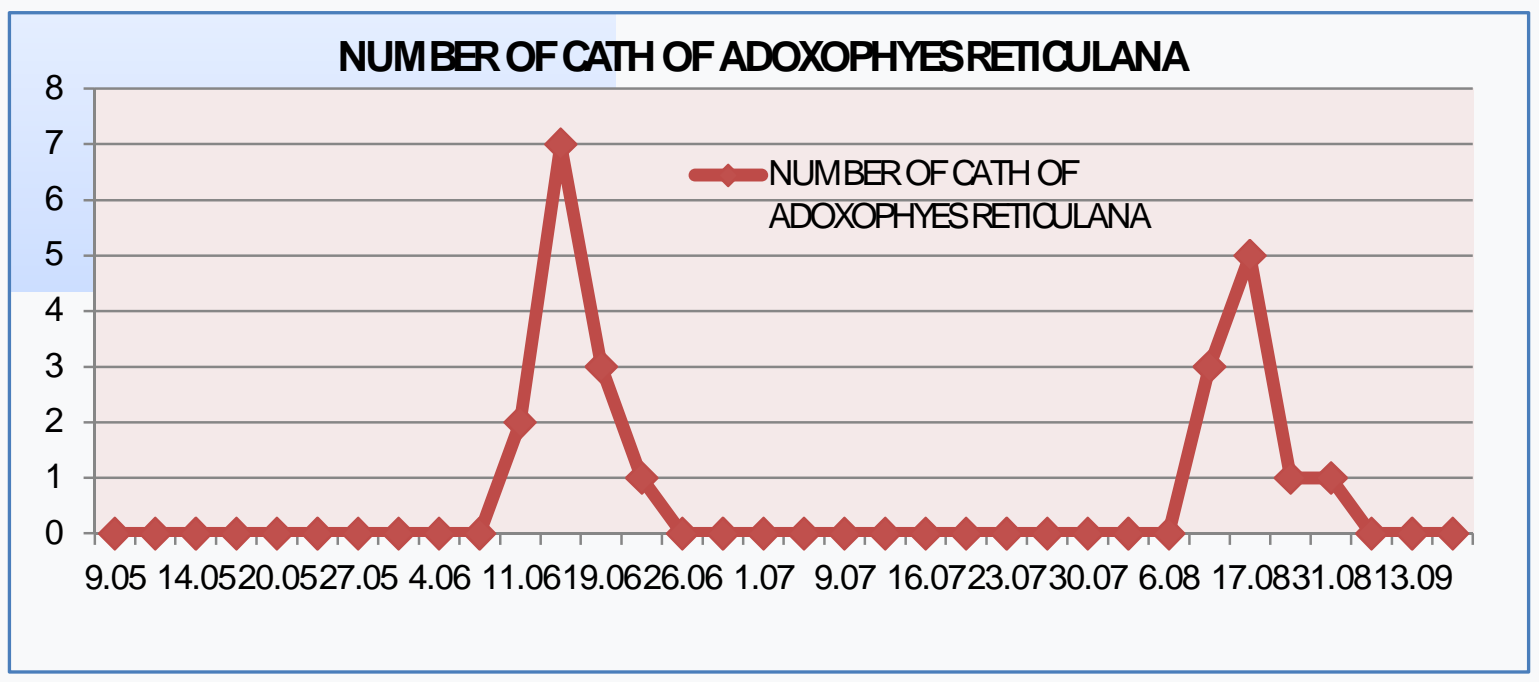

Figure 3. Analysis of flight curves of Adoxophyes reticulana $\mathrm{Hb}$

Compared to previous years, the second generation of this pest was not reported in large numbers, following observations of pheromone traps installed in the orchard. This is due to the application of 


\section{Current Trends in Natural Sciences}

Vol. 9, Issue 17, pp. 346-351, 2020

https://doi.org/10.47068/ctns.2020.v9i17.044

Current Trends in Natural Sciences (on-line)

ISSN: 2284-953X

Current Trends in Natural Sciences (CD-Rom)

ISSN: 2284-9521

ISSN-L: 2284-9521

ISSN-L: 2284-9521

phytosanitary treatments in combating the biological reserve of this pest and the good efficacy and wide spectrum of action of the insecticides used.

Phylonorichter blancardella F.recorded a permanent flight between May and September (figure 4), with high values for each maximum flight of the three generations, respectively of 150 butterflies on a trap at a reading in May, 300 butterflies on the trap in June and 2500 butterflies on the trap at the end of August.

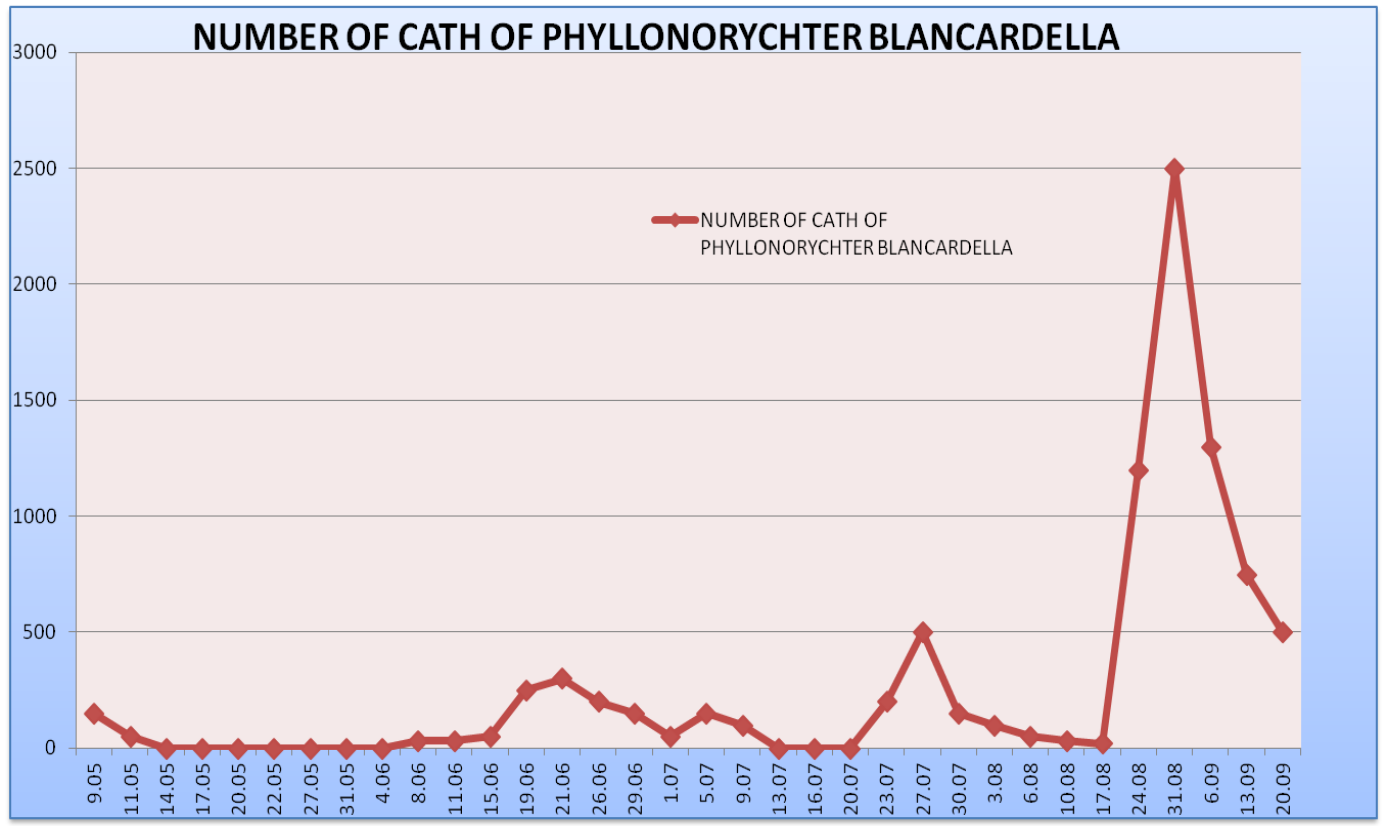

Figure 4. Analysis of flight curves of Phylonorichter blancardella

\section{CONCLUSIONS}

The conditions of 2019 were favorable for the development of the monitored apple pest species. The population density of the three lepidoptera was monitored in orchard conditions treated with the help of traps with specific pheromones, such as ATRAPOM, ATRARET and ATRABLANC. Insecticides were very effective in controlling these pests: Mospilan-0.03\% (0.45 kg / ha) for the pink bud phenophase and Reldan 22EC $-0.15 \%$ (2.2 1/ha) for fruit with a diameter $1 \mathrm{~cm}$, for the biological reserve of Adoxophyes reticulana larvae; Calypso -0.02\% (0.31/ ha) and Coragen 0.15 $1 /$ ha for the two generations of Cydia pomonella L..

The observations of the traps with sex pheromones allowed the permanent surveillance of the pest populations, depending on this, the optimal moment of applying the chemical treatments in the apple plantation was established.

\section{REFERENCES}

Bassi A., J. L. Rison, J. A. Wiles- Ch. (dpx-e2y45, rynaxypyr®, coragen®), A new diamide insecticide for control of codling moth (Cydia pomonella L.), colorado potato beetle (Leptinotarsa decemlineata) and european grapevine moth (Lobesia botrana)- https://pdfs.semanticscholar.org

Brunner, J., Welter S., Calkins C, Hilton R., Beers E, Dunley J, Unruh T./, Knight A., Steenwyk R.V., Buskirk P.V. (2002). Mating disruption of codling moth: a perspective from the Western United States, IOBC wprs Bulletin Vol. 25 (9), 11-19. 


\section{Current Trends in Natural Sciences}

Vol. 9, Issue 17, pp. 346-351, 2020

https://doi.org/10.47068/ctns.2020.v9i17.044

Current Trends in Natural Sciences (on-line)

ISSN: 2284-953X

Current Trends in Natural Sciences (CD-Rom)

ISSN: 2284-9521

ISSN-L: 2284-9521

ISSN-L: 2284-9521

Charmillot P.J. et Baggiolini, M. (1975). Essai de lutte contre le carpocapse (Laspeyresia pomonella L.) par capture intensive des mâles ŕ l'aide d'attractifs sexuels synthétiques [Codling moth (Laspeyresia pomonella L.) control test by intensive capture of males using synthetic sex attractants]. La Recherche agronomique en Suisse 14 (1), 71-77.

Charmillot P.J. et Bloesch B. (1987). La technique de confusion sexuelle: un moyen specifique de lutte contre le carpocapse Cydia pomonella L. Revue Suisse Vitic. Arboric. Hortic. [The mating disruption technique: a specific means of combating the codling moth Cydia pomonella L. Revue Suisse Vitic. Arboric. Hortic] 19(2), 129-138.

Ghizdavu, I. (1984). Cercetări de combatere a viermelui merelor Laspeyresia pomonella L. cu ajutorul feromonului sexual specific [Research to control apple worm Laspeyresia pomonella L. using specific sex pheromone] Buletin de protectia plantelor, 1(2-3), 7-15.

Howell, J.F. et al. (1992). Control of codling moth in apple and pear with sex pheromone mediated mating disruption. J. Ec. Entomol., 85(3), 918-925.

Iacob Maria (1977). Acțiunea feromonilor sexuali de sinteză în avertizarea tratamentelor de combatere a unor dăunători ai plantaţiilor pomicole şi viticole. [The action of synthetic sex pheromones in warning of the treatments to control some pests of the fruit and vine plantations.] Analele ICPP, XII, 197-215

Mesut İşci, Recep Ay (2017). Determination of resistance and resistance mechanisms to thiacloprid in Cydia pomonellaL. (Lepidoptera: Tortricidae) populations collected from apple orchards in Isparta Province, Turkey. Crop Protection, 91, 82-88.

Piskorski R., Dorn S. (2011). How the oligophage codling moth Cydia pomonella survives on walnut despite its secondary metabolite juglone, Journal of Insect Physiology, 57(6), 744-750.

Tălmaciu M. (2011). Protecția plantelor [Plant protection]. Entomologie. Editura „Ion Ionescu de la Brad”, Iaşi. 